\title{
High dispersity of carbon nanotubes diminishes immunotoxicity in spleen
}

\author{
This article was published in the following Dove Press journal: \\ International Journal of Nanomedicine \\ I April 2015 \\ Number of times this article has been viewed
}

\section{Soyoung Lee' \\ Dongwoo Khang ${ }^{2}$ \\ Sang-Hyun Kim'}

'CMRI, Department of Pharmacology, School of Medicine, Kyungpook National University, Daegu, Republic of Korea; ${ }^{2}$ Department of Molecular Medicine, Graduate School of Medicine, Gachon University, Incheon, Republic of Korea
Correspondence: Dongwoo Khang Department of Molecular Medicine, Graduate School of Medicine,

Gachon University, Incheon 406-840,

Republic of Korea

$\mathrm{Tel}+82328996515$

Fax +82328996515

Email dkhang@gachon.ac.kr

Sang-Hyun Kim

CMRI, Department of Pharmacology,

School of Medicine, Kyungpook

National University, Daegu 700-422,

Republic of Korea

Tel +82 534204838

Fax +82 534204838

Email shkim72@knu.ac.kr
Background: From the various physiochemical material properties, the chemical functionalization order of single-walled carbon nanotubes (swCNTs) has not been considered as a critical factor for modulating immunological responses and toxicological aspects in drug delivery applications. Although most nanomaterials, including carbon nanotubes, are specifically accumulated in spleen, few studies have focused on spleen immunotoxicity. For this reason, this study demonstrated that the dispersity of swCNTs significantly influenced immunotoxicity in vitro and in vivo.

Materials and methods: For cytotoxicity of swCNTs, MTT assay, reactive oxygen species production, superoxide dismutase activity, cellular uptake, and confocal microscopy were used in macrophages. In the in vivo study, female BALB/c mice were intravenously administered with $1 \mathrm{mg} / \mathrm{kg} /$ day of swCNTs for 2 weeks. The body weight, organ weight, hematological change, reverse-transcription polymerase chain reaction, and lymphocyte population were evaluated.

Results: Different orders of chemical functionalization of swCNTs controlled immunotoxicity. In short, less-dispersed swCNTs caused cytotoxicity in macrophages and abnormalities in immune organs such as spleen, whereas highly dispersed swCNTs did not result in immunotoxicity.

Conclusion: This study clarified that increasing carboxyl groups on swCNTs significantly mitigated immunotoxicity in vitro and in vivo. Our findings clarified the effective immunotoxicological factors of swCNTs by increasing dispersity of swCNTs and provided useful guidelines for the effective use of nanomaterials.

Keywords: carbon nanotubes, immunotoxicity, dispersity, physicochemical property

\section{Introduction}

Due to intrinsic nanosize and easy to surface functionalization, carbon nanotubes (CNTs) have engendered great interest in nanomedicine. ${ }^{1,2}$ In addition, the nearinfrared optical absorption of CNTs have been exploited for laser-heating cancer therapy, and their unusual hollow nanostructure makes CNTs useful as novel drug and gene delivery agents. ${ }^{3-5}$ Functionalized CNTs with good water solubility and biocompatibility can cross cell membranes, transporting a wide range of biologically active molecules, including drugs, proteins, DNA, and RNA, into cells. ${ }^{6,7}$ Previous studies focused heavily on the size and chemical composition of nanomaterials and their relationship with cytotoxicity. ${ }^{8}$ It was unclear, however, if there are any other influential physicochemical material factors that can control immunotoxicity. Thus, a more strict approach to exposure and production of CNTs is required to minimize potential hazards by controlling physicochemical material properties. ${ }^{9}$

Most nanomaterials are accumulated in specific organs, such as liver and spleen, and cleared by the blood circulatory system. ${ }^{10}$ However, spontaneous exposure of nanomaterials to immune-specific organs, such as spleen and lymph node, can stimulate the immune system and can trigger subsequent toxicity. For this reason, 
a more stringent examination of immune organs is essential before clinical application. ${ }^{11}$

Single-walled carbon nanotubes (swCNTs) are thought to disturb systemic immune function, promote allergic responses, and cause platelet activation and a prothrombotic state. ${ }^{12-14}$ In fact, many toxicological studies have reported adverse health effects such as pulmonary inflammation, glaucomatous lesions, fibrosis, and mesothelioma after administration of swCNTs into the lungs. ${ }^{15-17}$ Specifically, several in vitro studies have demonstrated that swCNTs exhibit substantial cytotoxicity, including induction of oxidative stress and apoptosis, as well as inhibition of cellular proliferation. ${ }^{18}$

Since individual CNTs have a very high aspect ratio, they easily agglomerate into micrometer structures in dry or suspension states. ${ }^{19,20}$ In this light, studies indicate that toxicity by CNTs is affected by changes in CNT physical and material properties, such as fiber length, diameter, surface area, agglomeration, and dispersity in aqueous systems. ${ }^{21-23}$ Previous in vitro studies reported that CNT toxicity is related to different degrees of CNT dispersion caused by altered surface chemistry. ${ }^{23}$ Additionally, several studies have shown that the behavior of swCNTs is highly dependent on their surface chemistry in vitro (for cellular uptake) and in vivo (for blood circulation time and biodistribution). ${ }^{24,25}$ In most biodistribution studies, swCNTs exhibited selective accumulation in spleen. ${ }^{26}$ However, despite selective accumulation of swCNTs in spleen, no clear immunotoxicity in spleen due to changes in material properties of swCNTs was suggested. Thus, effective physiochemical factors for determining in vivo spleen immune-toxicity were not clarified. In this study, we elucidated the importance of hydrophilic oxide surface content on swCNTs (which determines dispersion constant of suspended swCNTs in water) as one of the influential factors for modulating spleen immunotoxicity.

\section{Materials and methods}

\section{Controlling surface carboxylate of single-walled carbon nanotubes}

Purified swCNTs were purchased (900-1351, SES Research) and different orders of carboxylate CNTs were generated. Carboxylation is the most common functionalization to enhance water solubility of swCNTs, and in this study, three different degrees of carboxylation (COOH-low, $\mathrm{COOH}-\mathrm{mid}$, and $\mathrm{COOH}-\mathrm{max}$ ) were generated using previously suggested protocols. ${ }^{27}$ To generate COOH-low groups, $10 \mathrm{mg}$ of swCNTs were mixed with $3 \mathrm{~mL}$ of $\mathrm{H}_{2} \mathrm{SO}_{4}$ and $1 \mathrm{~mL}$ of $\mathrm{HNO}_{3}$. The mixed solution was stirred with a magnetic stir bar for 14 hours at room temperature. Next, the solution was diluted with deionized water $(1: 200 \mathrm{v} / \mathrm{v})$, filtered $(200 \mathrm{~nm}$ pore size PTFE; EMD Millipore, Billerica, MA, USA) and washed out several times to completely remove any residual solvent on the CNTs. The swCNTs were then dried in a vacuum oven at $60^{\circ} \mathrm{C}$ overnight. To generate more carboxyl groups (COOH-mid), $10 \mathrm{mg}$ of swCNTs were mixed with $3 \mathrm{~mL}$ of $\mathrm{H}_{2} \mathrm{SO}_{4}$ and $1 \mathrm{~mL}$ of $\mathrm{HNO}_{3}$. The prepared solution was stirred using a magnetic stir bar for 30 minutes at room temperature and sonicated for 99 minutes. The solution was then diluted, filtered and dried. To generate the greatest order of carboxyl groups (COOH-max), $20 \mathrm{mg}$ of swCNTs were immersed in $9 \mathrm{~mL}$ of $\mathrm{H}_{2} \mathrm{SO}_{4}$ and $3 \mathrm{~mL}$ of $\mathrm{HNO}_{3}$ by sonication in a water bath for 30 minutes and stirred with a magnetic bar for 24 hours at $50^{\circ} \mathrm{C}$. The samples were washed, filtered, and dried following the same protocols as previously described.

\section{Size and surface chemistry of different orders of functionalized swCNTs}

The evidence of carboxyl groups on the CNT surface was chemically identified by Fourier transform infrared spectroscopy (FTIR; VERTEX 80v; Bruker Optics Inc, Billerica, MA, USA). Samples were prepared by grinding the CNTs in an agate mortar with $\mathrm{KBr}$ and subjected to $70 \mathrm{MPa}$ of applied pressure. The transparent flakes were analyzed within the mid-infrared wavelengths $\left(400-4,000 \mathrm{~cm}^{-1}\right)$. To analyze the oxide amount on each carboxylate swCNTs, X-ray photoelectron spectroscopy (Thermo Fisher Scientific, Waltham, MA, USA) was performed to determine the atomic weight ratio. Electron spectroscopy for chemical analysis was carried out for $\mathrm{C} 1 \mathrm{~s}$ (carbon) and O1s (oxygen) peaks to compare comparative areas of each curve representing the atomic weight ratio. Quantitative analysis of weight amount of functionalized groups (carboxyl) was analyzed by thermal gravimetric analysis (TGA; Q50; TA Instruments, New Castle, DE, USA). Ten milligrams of swCNTs were heat-treated at $60^{\circ} \mathrm{C}$ for 3 hours in vacuum before TGA to evaporate remaining water molecules from the surfaces. TGA was performed with increasing temperature at $10^{\circ} \mathrm{C} /$ minute with $\mathrm{N}_{2}$ supplement of $100 \mathrm{~mL} /$ minute. Particle size analyzer (Zetasizer Nano; Malvern Instruments, Malvern, UK) was performed to analyze particle size of used swCNTs in water.

Mouse plasma samples were obtained from healthy individuals. Blood from each donor was collected in heparin sodium and centrifuged for 5 minutes at $800 \mathrm{~g}$ to pellet the blood cells. The supernatants (plasma) were combined and stored in aliquots at $-80^{\circ} \mathrm{C}$. One $\mathrm{mg} / \mathrm{mL}$ swCNT in phosphate buffered saline (PBS) were incubated with $10 \%$ plasma at 
$37^{\circ} \mathrm{C}$ for 1 hour. After incubation, unbound proteins were separated from the swCNT by centrifuging 12,000 $\mathrm{g}$ for 1 hour at $4^{\circ} \mathrm{C}$. Plasma without swCNT was used as a control. Particle pellets were carefully washed with the PBS buffer twice, and resuspended in sodium dodecyl sulfate sample buffer. Samples were then heated at $95^{\circ} \mathrm{C}$ for 5 minutes to dissociate particle-bound proteins.

\section{Cell culture and viability}

The BALB/c macrophage cell line J774A.1 (TIB-67; American Type Culture Collection, Manassas, VA, USA), was cultivated in Dulbecco's minimum essential medium and supplemented with $2 \mathrm{mM}$ glutamine, $100 \mathrm{U} / \mathrm{mL}$ penicillin, $100 \mu \mathrm{g} / \mathrm{mL}$ streptomycin ( $1 \%$ antibiotics), and $10 \%$ non-heat-inactivated fetal bovine serum (FBS; Thermo Fisher Scientific, Waltham, MA, USA), under standard cell culture conditions $\left(5 \% \mathrm{CO}_{2}\right.$ at $\left.37^{\circ} \mathrm{C}\right)$. Cells were seeded at a density of $2 \times 10^{4}$ cells/well in 96-well plates, and treated with various concentrations of swCNTs for 24 hours. Cell viability was determined using the MTT assay (Sigma Chemicals, Perth, WA, Australia). Specifically, MTT (10 mg/mL) was added into each well that contained a sample and incubated for 4 hours. Isopropanol (in $0.04 \mathrm{~N}-\mathrm{HCl}$ ) was added to dissolve the formazan crystals. Absorbance was read at 570 $\mathrm{nm}$ using a spectrophotometer. Cell viability, defined as the relative absorbance on each sample compared to that of the control, was calculated and expressed as percentage.

\section{NO assay}

The amount of stable nitrite, which is the final NO product generated by activated macrophages, was determined with a colorimetric assay after 24 hours of cell seeding $\left(5 \times 10^{4}\right.$ cells/ well). Briefly, $50 \mu \mathrm{L}$ of culture supernatant was mixed with an equal volume of Griess reagent ( $1 \%$ sulfanilamide, $0.1 \%$ naphthylethylenediamine dihydrocholoride, $2.5 \% \mathrm{H}_{3} \mathrm{PO}_{4}$ ) and incubated at room temperature for 10 minutes. The absorbance at $540 \mathrm{~nm}$ was read using a spectrophotometer. Nitrite concentration was determined by extrapolation from a sodium nitrite standard curve.

\section{Fluorescence imaging}

Cells were cultured on poly-D-lysine-coated coverslips for 24 hours and fixed with 4\% paraformaldehyde in medium overnight at $4^{\circ} \mathrm{C}$. Permeabilization was done in PBS with $0.1 \%$ Triton $\mathrm{X}-100$ for 15 minutes at room temperature. After blocking for 2 hours with 1\% bovine serum albumin (AMRESCO LLC, Solon, OH, USA) in PBS, cells were incubated with F-actin (1:500; Thermo Fisher Scientific) antibody overnight at $4^{\circ} \mathrm{C}$ in the absence of light. After washing, cells were mounted using ProLong ${ }^{\circledR}$ Gold antifade reagent with 4',6-diamidino-2-phenylindole (DAPI; Thermo Fisher Scientific) stains. Cells were visualized using fluorescence microscopy (Olympus Corporation, Tokyo, Japan) with metamorph analysis (Olympus).

\section{Reactive oxygen species generation}

The production of reactive oxygen species (ROS) was measured by detecting the fluorescent intensity of oxidantsensitive probe dihydrorhodamine 123 (DHR). Cells $\left(2 \times 10^{4}\right.$ cells/well in 96-well plates) were washed with PBS. PBS was supplemented with $10 \mu \mathrm{M}$ of DHR, and the intracellular and extracellular dye concentrations were allowed to equilibrate at $5 \% \mathrm{CO}_{2}$ at $37^{\circ} \mathrm{C}$ for 30 minutes. Iron $\left(\mathrm{FeSO}_{4}, 100 \mu \mathrm{M}\right)$ was used as a positive control for ROS generation. The cells were then incubated with swCNT for 24 hours and the fluorescent intensity for DHR was recorded using fluorescent plate reader (Fluostar OPTIMA; BMG Labtech GmbH, Offenburg, Germany) at excitation of $480 \mathrm{~nm}$ and emission of $525 \mathrm{~nm}$. The fluorescent readings were digitized using Soft Max Pro (Molecular Devices LLC, Sunnyvale, CA, USA).

\section{Enzyme activity assay for superoxide dismutase}

Superoxide dismutase (SOD) activity was measured using the tetrazolium-based SOD assay kit (Sigma) as directed by the manufacturer. Cell pellets were resuspended in cold buffer (50 mM Tris-HCL, pH 7.5, 5 mM ethylenediaminetetraacetic acid, and $1 \mathrm{mM}$ 1,4-dithiothreitol) and centrifuged at $10,000 \mathrm{~g}$ for 15 minutes at $4^{\circ} \mathrm{C}$. Sample solution was mixed with to each sample and blank 2 well. dd- $\mathrm{H}_{2} \mathrm{O}$ was mixed with each blank 1 and blank 3 well. Enzyme working solution was mixed with each sample and blank 1 well, incubated the plate at $37^{\circ} \mathrm{C}$ for $20 \mathrm{~min}(450 \mathrm{~nm})$.

\section{Animals and treatment}

Female BALB/c mice ( 8 weeks old) were purchased from Dae-Han Experimental Animal Center (Daejeon, Korea). The animals were housed in a laminar air-flow room maintained under a temperature of $22^{\circ} \mathrm{C} \pm 2{ }^{\circ} \mathrm{C}$ and relative humidity of $55 \% \pm 5 \%$ throughout the study. The care and treatment of the animals were in accordance with the guidelines established by the Public Health Service Policy on the Humane Care and Use of Laboratory Animals and were approved by the Institutional Animal Care and Use Committee.

Mice were administered intravenously with swCNT $(1 \mathrm{mg} / \mathrm{kg} /$ day) for 2 weeks. At the end of treatment period, 
mice were fasted overnight and euthanized by carbon dioxide. Trunk blood was collected, and various organs were aseptically excised and weighed.

\section{Splenic T lymphocyte population and splenocytes proliferation}

Single-cell splenocytes were prepared as described earlier, ${ }^{10}$ with modifications as noted below. Spleen was aseptically excised and maintained in $10 \mathrm{~mL}$ of cold complete Roswell Park Memorial Institute medium (RPMI) medium (RPMI1640 with $10 \%$ heat-inactivated FBS and $1 \%$ antibioticantimycotic). Monocellular suspensions were prepared using a Stomacher laboratory blender (Stomacher 80; Seward Ltd, Thetford, UK). The cells were resuspended in medium.

Monoclonal antibodies were conjugated to fluorescein isothiocyanate (FITC, emission at $525 \mathrm{~nm}$ ). Antibodies to cell-specific receptors (Santa Cruz Biotechnology Inc., Dallas, TX, USA) included anti-mouse CD3-FITC (T lymphocyte). Cells were washed in PBS, and antibody was added to samples, vortexed gently, and followed by incubation at $4^{\circ} \mathrm{C}$ for 30 minutes. Cells were analyzed using a flow cytometer (BD Biosciences, San Jose, CA, USA).

Single-cell splenocytes were dispensed into 96-well plates containing $10 \mu \mathrm{g} / \mathrm{mL}$ of Concanavalin $\mathrm{A}$ (Con A), and further incubated for 72 hours. The proliferation of splenocytes was determined by MTT assay. Cell proliferation was presented by the relative absorbance from Con A-stimulated control splenocytes.

\section{Real-time polymerase chain reaction}

The total cellular RNA was isolated from cells $\left(2 \times 10^{5}\right.$ cells/well in 24-well plate). First strand complimentary DNA (cDNA) was synthesized from $2 \mu \mathrm{g}$ of total RNA, using a Maxime RT-PreMix Kit (iNtRON Biotechnology, Daejeon, Korea). The respective primers were chosen by the Primer 3 program (Whitehead Institute for Biomedical Research, Cambridge, MA) and all primers were obtained from Genotech (Daejeon, Korea). Polymerase chain reaction (PCR) was carried out with the following primers: tumor necrosis factor (TNF)- $\alpha$ (F 5'-GGC AGG TCT ACT TTG GAG TCA TTG C-3'; R 5'-ACA TTC GAG GCT CCA GTG AAT TCG G-3'), interleukin (IL)-1 $\beta$ (F 5'-ATA ACC TGC TGG TGT GTG AC-3'; R 5'-AGG TGC TGA TGT ACC AGT TG-3'), and IL-2 (F 5'-TGC AAC GTT GGA AAG GAA AG-3'; R 5'-TAC CTA CGC AGC CCT GAT TG - $3^{\prime}$ ). $\beta$-actin (F $5^{\prime}$-TAG ACT TCG AGC AGG AGA TG-3'; R 5'-TTG ATC TTC ATG GTG CTA GG-3') was used to verify the equal amounts of cDNA. Quantitative real-time PCR was carried out to verify mRNA expression, using the Thermal Cycler Dice Real Time System (TP-800; Takara Bio Inc., Otsu/Shiga, Japan). Briefly, $2 \mu \mathrm{L}$ of cDNA (100 ng), $1 \mu \mathrm{L}$ each of sense and antisense primer solution $(0.4 \mu \mathrm{M}), 12.5 \mu \mathrm{L}$ of SYBR Premix Ex Taq, and $9.5 \mu \mathrm{L}$ of $\mathrm{dH}_{2} \mathrm{O}$ were mixed together to obtain a final $25 \mu \mathrm{L}$ reaction mixture in each reaction tube. The amplification conditions were 10 seconds at $95^{\circ} \mathrm{C}, 40$ cycles of 5 seconds at $95^{\circ} \mathrm{C}$ and 30 seconds at $60^{\circ} \mathrm{C}, 15$ seconds at $95^{\circ} \mathrm{C}, 30$ seconds at $60^{\circ} \mathrm{C}$, and 15 seconds at $95^{\circ} \mathrm{C}$. Relative quantification of mRNA expression was performed using the TP850 software. Lipopolysaccharide was used as a positive control.

\section{Statistical analysis}

Statistical analyses were performed using the SAS statistical software (SAS Institute Inc., Cary, NC, USA). Treatment effects were analyzed using one-way analysis of variance, followed by Duncan's multiple range tests. Statistical significance was set at $P<0.05$.

\section{Results and Discussion Physiochemical material properties of swCNTs}

Functionalization of swCNTs with carboxyl $(\mathrm{COOH})$ terminated groups were successfully generated by the previous suggested protocols. ${ }^{27}$ FTIR confirmed increased carboxyl bonds at $1,724\left(\mathrm{~cm}^{-1}\right)$ with reduction of $\mathrm{C}=\mathrm{C}$ bonds at $1,631\left(\mathrm{~cm}^{-1}\right)$ due to the breaking of carbon crystals from oxidation after acidic treatment (Figure S1A). Electrical potential also identified the surface charge of each functionalized swCNT (Figure 1C). Incremental carboxyl anions $\left(\mathrm{COOH}^{-}\right)$ were generated in ranges from $\mathrm{COOH}$-low to $\mathrm{COOH}$-mid to $\mathrm{COOH}-\mathrm{max}$. Greater presence of anions resulted in increase of negative potential, as identified by Figure 1C.

Due to less presence of carboxylate anions, sediment of $\mathrm{COOH}-$ low was additionally centrifuged, and only suspended solutions were taken for further experiments. In this way, all samples were suspended at PBS but possess different order of carboxyl functionalization amount. Based on the particle size analysis, highly dispersed swCNTs corresponded to greater carboxyl groups and showed a relatively broad spectrum of particle sizes, with smaller size than $\mathrm{COOH}-\mathrm{low}$, whereas less-dispersed swCNTs (COOH-low) showed sharp localization of particle sizes but bigger size than $\mathrm{COOH}$ mid and COOH-max (Figure 1A). Amount of adsorbed plasma proteins revealed the greatest adsorption amount on $\mathrm{COOH}$-max compared to $\mathrm{COOH}$-mid and $\mathrm{COOH}$-low (inset image of Figure 1A). This result was identical to the greatest 
A
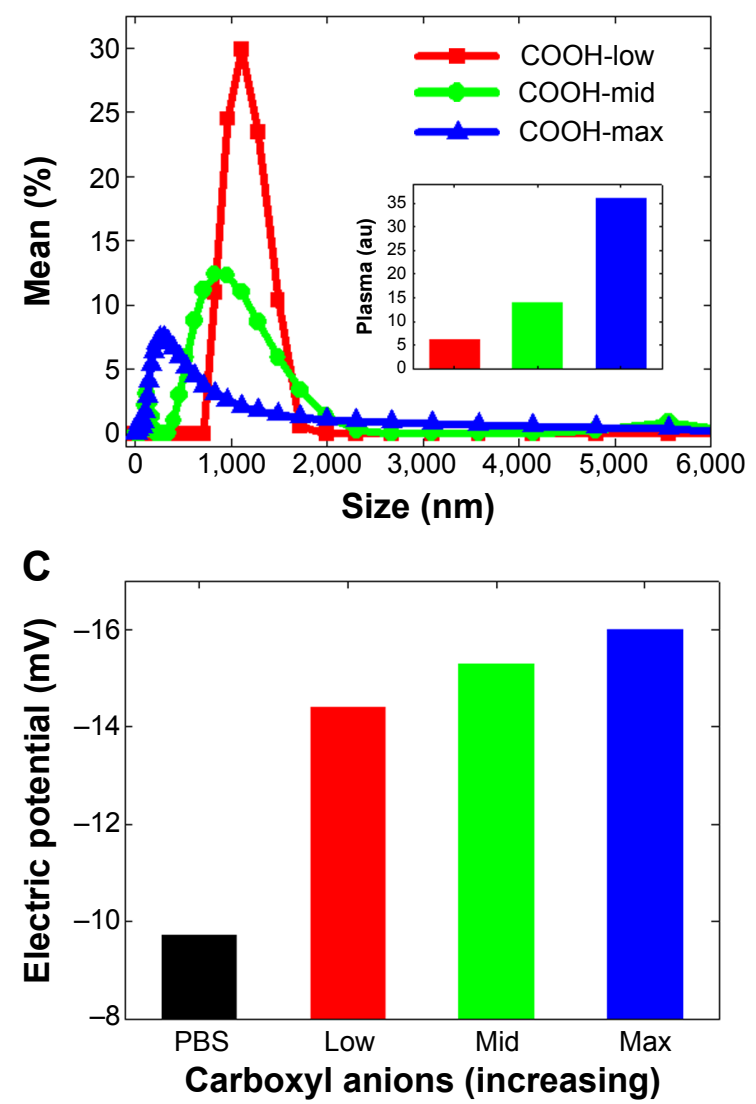

B

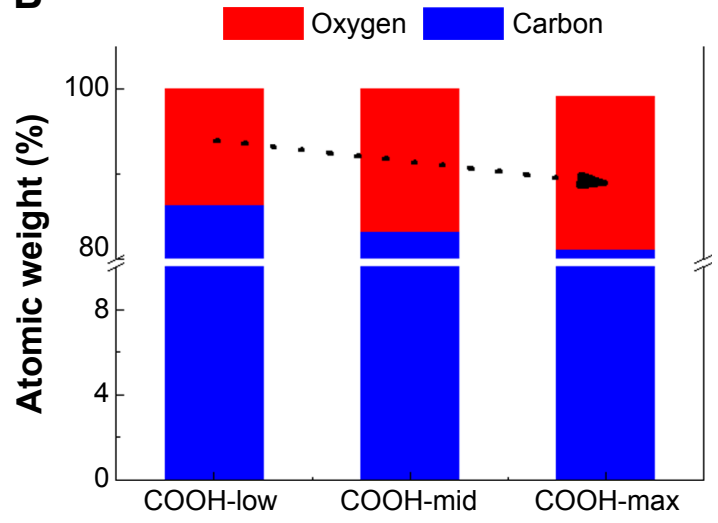

D

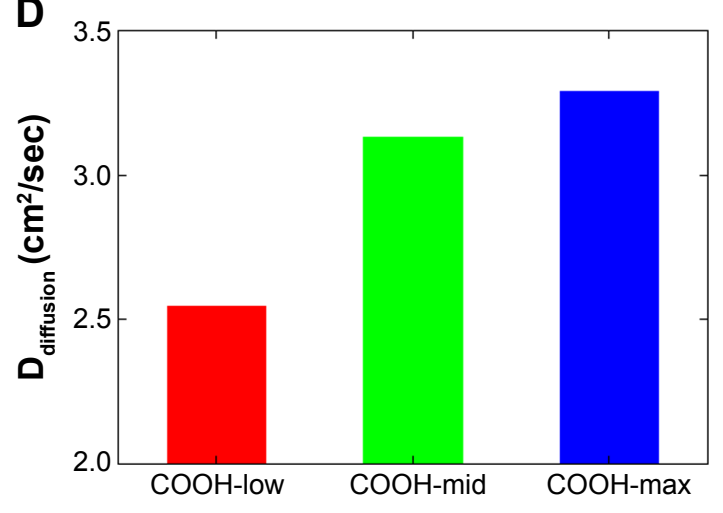

Figure I Particle size and electric potential of single-walled carbon nanotubes with different order of dispersion (carboxylation).

Notes: (A) Particle size analysis of $\mathrm{COOH}-\mathrm{low}, \mathrm{COOH}$-mid, and $\mathrm{COOH}$-max functionalized swCNTs in PBS showed greater particle size as decreasing carboxylation and increasing narrow spectrum of size distribution. Inset image shows greater amount of plasma adsorption on swCNTs with increasing carboxylation. (B) XPS shows increasing oxide atoms with increasing order of carboxylation (COO-). (C) Zeta potential shows increase of negative charges with increasing carboxyl anions in PBS. (D) Diffusion constant (proportional to dispersity) in PBS shows greater diffusion constant with increasing carboxylation.

Abbreviations: PBS, phosphate-buffered saline; swCNT, single-walled carbon nanotube; XPS, X-ray photoelectron spectroscopy.

adsorption amount of FBS $10 \%$ protein on $\mathrm{COOH}-\max$ compared to $\mathrm{COOH}-\mathrm{mid}$ and $\mathrm{COOH}-\mathrm{low} .{ }^{27}$ Greater plasma protein adsorption on high-carboxyl carbon structures than on less-carboxyl structures might be due to increased surface area in a given volume (nonspecific hydrophobic adsorption). This is because most plasma proteins in PBS did not result in change of electric potential (plasma proteins were neutral in PBS) and thus, electric interaction between plasma and each degree of carboxylate nanotubes was not significant.

TGA curves show different carboxyl weight for each of the functionalized swCNTs. The concentration of carboxyl groups corresponded to $2.72 \mathrm{mmol} / \mathrm{g}, 4.71 \mathrm{mmol} / \mathrm{g}$, and $4.94 \mathrm{mmol} / \mathrm{g}$ for $\mathrm{COOH}-\mathrm{low}, \mathrm{COOH}-\mathrm{mid}$, and $\mathrm{COOH}-\mathrm{max}$, respectively (based on the percentage of weight loss temperatures between $200^{\circ} \mathrm{C}$ and $480^{\circ} \mathrm{C}$; Figure S1B).$^{28}$ As such, the amount of carboxyl weight on the differently functionalized swCNTs showed slight difference in carboxyl weight between $\mathrm{COOH}$-mid and $\mathrm{COOH}-$ max whereas $\mathrm{COOH}-\mathrm{low}$ exhibited less carboxyl groups compared to $\mathrm{COOH}-$ mid and COOH-max (Figure S1B).

In addition, the most-dispersed $\mathrm{COOH}(\mathrm{COOH}-\mathrm{max})$ exhibited the highest oxygen atomic content at $290 \mathrm{eV}$ (CO and $\mathrm{C}=\mathrm{O}$ ), which corresponded with $30 \%$ of oxygen on carbon (weight ratio), whereas $\mathrm{COOH}-$ low corresponded with $25 \%$ of oxide, as identified by X-ray photoelectron spectroscopy (Figure 1B). Changing the carboxyl degree of functionality directly influenced the dispersity of swCNTs (Figure 1D). Diffusion constant, defined as $\mathrm{D}_{\text {diffusion }}$ : diffusivity with the dimension of length ${ }^{2} /$ time $^{-1}$, recorded highest value for the greatest oxide amounted carbon surfaces (COOH-max) compared to $\mathrm{COOH}-$ mid and $\mathrm{COOH}-\mathrm{low}$ in water (Figure 1D). This physical value is directly correlated to dispersity of swCNTs in water. The surface charges measurement of three different carboxyl groups showed increasing negative potential as carboxylation increases (greater presence of anions: $\mathrm{COO}^{-}$) (Figure 1C). 


\section{Increasing hydrophilicity of swCNTs mitigates immunotoxicity}

Viability of macrophages (J774A.1) was analyzed using MTT assay to investigate whether differently dispersed swCNTs induce different levels of cytotoxicity after 24 hours exposure (Figure 2A). The COOH-max (highly dispersed) particles were less toxic than the $\mathrm{COOH}-\mathrm{low}$ and $\mathrm{COOH}$-mid particles and showed the lowest cytotoxicity toward macrophages. Hydrogen peroxide was used as a positive control. In addition, we observed the cellular uptake of dispersed swCNTs by densitometric analysis (Figure 2B) and confocal microscopy (Figure 2C). Cells were treated with each dispersed swCNT
A

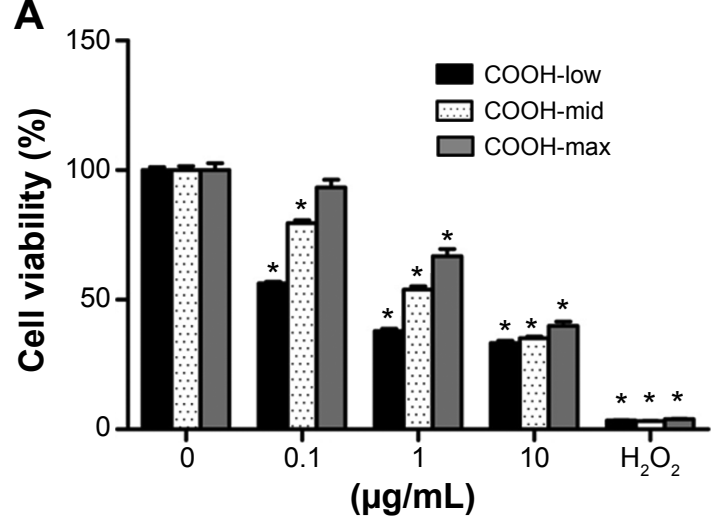

C
B
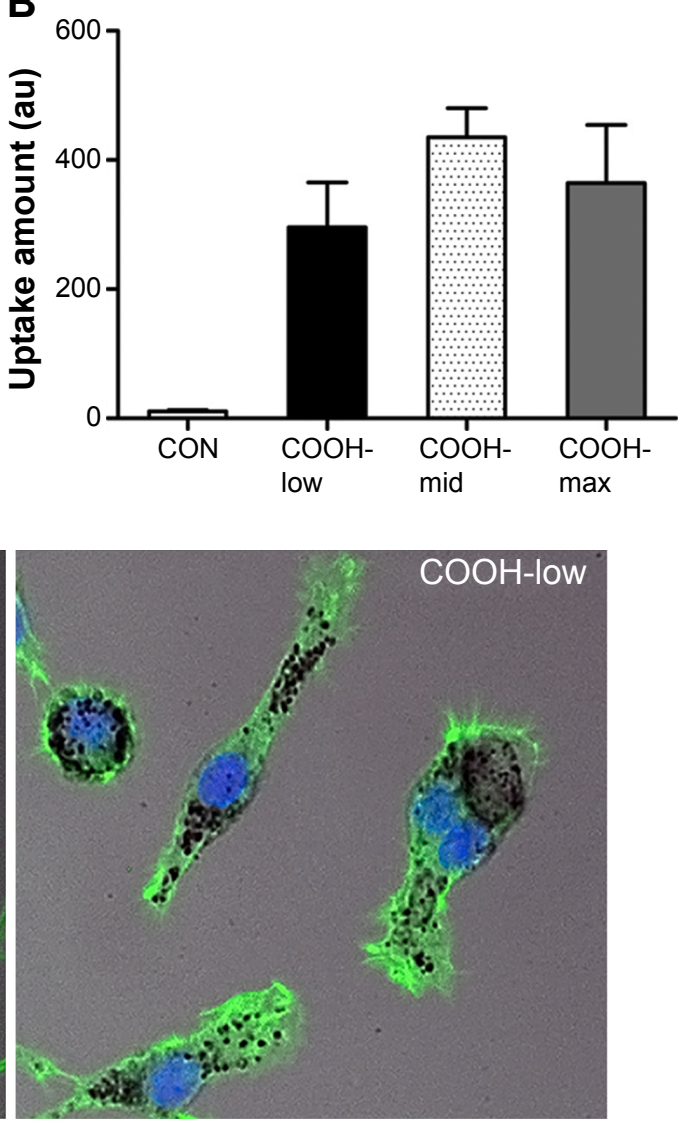
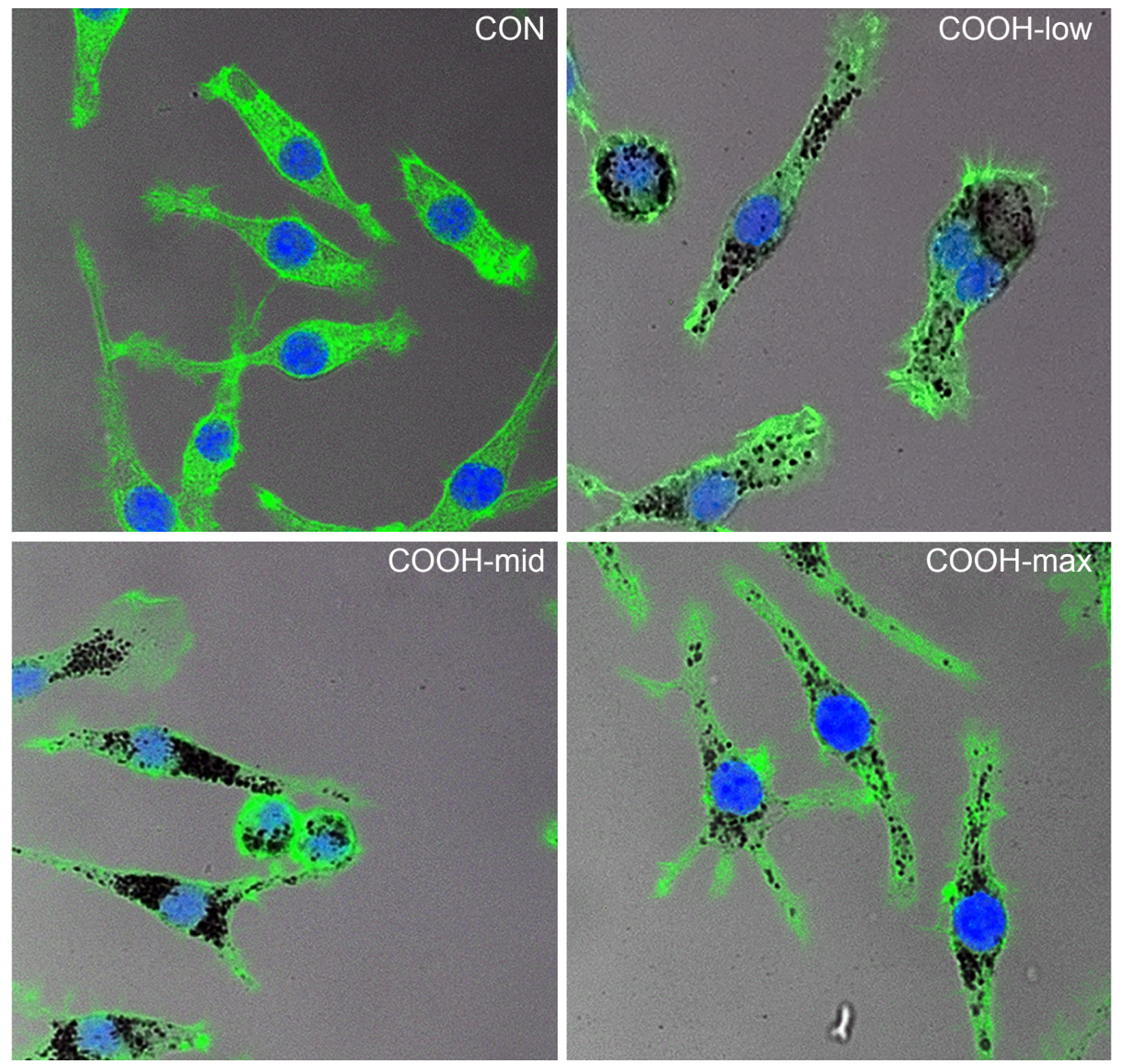

Figure 2 Effects of dispersed single-walled carbon nanotubes on cytotoxicity and level of cellular uptake in macrophages.

Notes: (A) Cells $\left(2 \times 10^{4}\right.$ cells/well in 96 -well plates) were treated with various concentrations of dispersed swCNTs. After 24 hours of treatment, cell viability was determined using the MTT assay. Hydrogen peroxide $(500 \mu \mathrm{M})$ was used as a positive control. Cell viability was determined by the relative absorbance compared to control. (B, C) Cells $\left(2 \times 10^{5}\right.$ cells/well in 4-well plates) were treated with I $\mu \mathrm{g} / \mathrm{mL}$ swCNTs for 24 hours. After treatment with swCNTs, the cells were stained with F-actin (green) and DAPI (blue). Images showed intracellular location of swCNTs (black). The fluorescence was visualized using (B) densitometric analysis and (C) confocal microscopy $(\times 400)$. The results are presented as mean \pm SE of three independent experiments. $* P<0.05$ significantly different from control.

Abbreviations: CON, control; DAPI, 4',6-diamidino-2-phenylindole; MTT, 3(4, 5-dimethylthiazolyl-2)2,5-diphenyl tetrazolium bromide; PBS, phosphate-buffered saline; SE, standard error; swCNT, single-walled carbon nanotube; XPS, X-ray photoelectron spectroscopy. 
( $1 \mu \mathrm{g} / \mathrm{mL}$ ) for 24 hours and stained with F-actin-FITC and DAPI for actin and nuclei, respectively. Confocal microscopy showed that differently dispersed swCNTs were similarly translocated into the cytoplasm (Figures $2 \mathrm{C}$ and S2). These results suggest that each dispersed swCNT (COOH-low, -mid, and -high) induced different cytotoxicities, whereas differently dispersed swCNTs were similarly translocated into the cytoplasm after cellular uptake.

Next, to understand the molecular events involved in swCNT-induced cytotoxicity, the effects of differently dispersed swCNTs on ROS production (Figure 3A) and SOD activity (Figure 3B) were analyzed. Oxidative stress is a common mechanism for cell damage induced by nanoparticles and ultrafine particles, and various nanomaterials have been shown to produce ROS. ${ }^{29,30}$ ROS are stable and highly reactive compounds that can strip electrons from cellular macromolecules and render them dysfunctional. ${ }^{31}$ Chain reactions of self-propagating free radicals (molecules that contain an unpaired electron in their outermost shell) mediate lipid peroxidation and cause cell membrane structure damage, thereby inducing cell death. ${ }^{32,33}$ The accumulation of ROS, superoxide radicals, and hydroxyl free radicals depleted cellular glutathione and minimized the defensive effects of cellular antioxidant enzymes such as SOD. ${ }^{34}$ In our study, the COOH-max showed much less ROS production and SOD activity than that shown by the less-dispersed swCNTs (Figure 3). These results were confirmed using other immune cell types such as T cells (Jurkat cells) and monocytes (THP-1) (Figure S3). The COOH-max showed less cytotoxicity and ROS production in both Jurkat cells and THP-1. Thus, we concluded that increasing dispersion induces less cytotoxicity and decreased ROS production and SOD activity.

Although each dispersed swCNT (COOH-low, -mid, and -high) was similarly translocated into the cytoplasm after cellular uptake (Figure 2C), COOH-max particles induced lower NO production and expression of proinflammatory cytokines such as IL-1 $\beta$ and TNF- $\alpha$ (Figure 4A-C). These results suggest that different degrees of swCNT dispersion cause different toxicity and inflammatory responses, although all degrees of swCNT dispersion resulted in similar cellular uptake.

In some studies, swCNTs with different degrees of agglomeration were investigated in primary cultures derived from chicken embryonic spinal cord or dorsal root ganglia. ${ }^{35}$ In this primary cultures study, cytotoxicity was more pronounced on highly agglomerated swCNTs as than on the cells exposed to the better-dispersed swCNT bundles. Other in vitro experiments using human mesothelioma cell line MSTO-211H indicated stronger cytotoxic effects of agglomerated swCNTs compared to well-dispersed nanotubes. ${ }^{23}$ Therefore, the dispersity of swCNTs can play an important role in determining their cytotoxicity.

To confirm the cytotoxicity of differently dispersed swCNTs, an in vivo experiment was performed to analyze the immunotoxicity of dispersed swCNTs $(1 \mathrm{mg} / \mathrm{kg} /$ day, administered by intravenous injection during 2 weeks). Neither mean body weight (Figure S4A) nor food and water consumption (data not shown) was altered by swCNTs treatment. No significant changes in tissue weights were detected in given administration (Figure S4B). However, the white
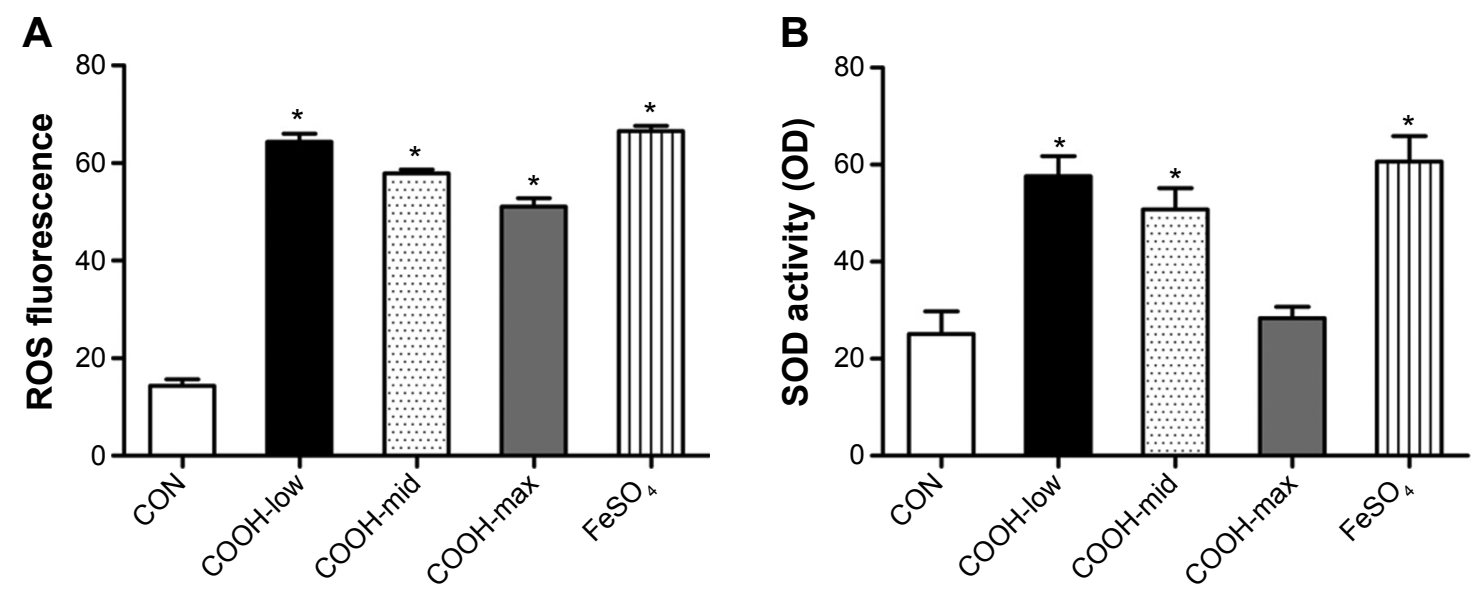

Figure 3 Effects of dispersed single-walled carbon nanotubes on oxidative stress.

Notes: (A) Cells $\left(2 \times 10^{4}\right.$ cells/well in 96 -well plates) were treated with I $\mu \mathrm{g} / \mathrm{mL}$ swCNTs for 24 hours. After treatment, the cells were stained with I0 $\mu$ M DHR I 23 for 30 minutes. Production of ROS was determined using DHR 123 staining. The fluorescent intensity of DHR was recorded using a fluorescent plate reader. (B) Cells ( $2 \times 10^{6}$ cells/well in 6-well plates) were treated with I $\mu \mathrm{g} / \mathrm{mL}$ swCNTs for 24 hours. Superoxide dismutase (SOD) activity was determined using a tetrazolium-based SOD assay kit. $\mathrm{FeSO}_{4}(100 \mu \mathrm{M})$ was used as a positive control. The results are presented as mean $\pm \mathrm{SE}$ of three independent experiments. *P<0.05 significantly different from control. Abbreviations: CON, control; DHR, dihydrorhodamine; ROS, reactive oxygen species; SE, standard error; SOD, superoxide dismutase; swCNT, single-walled carbon nanotube. 

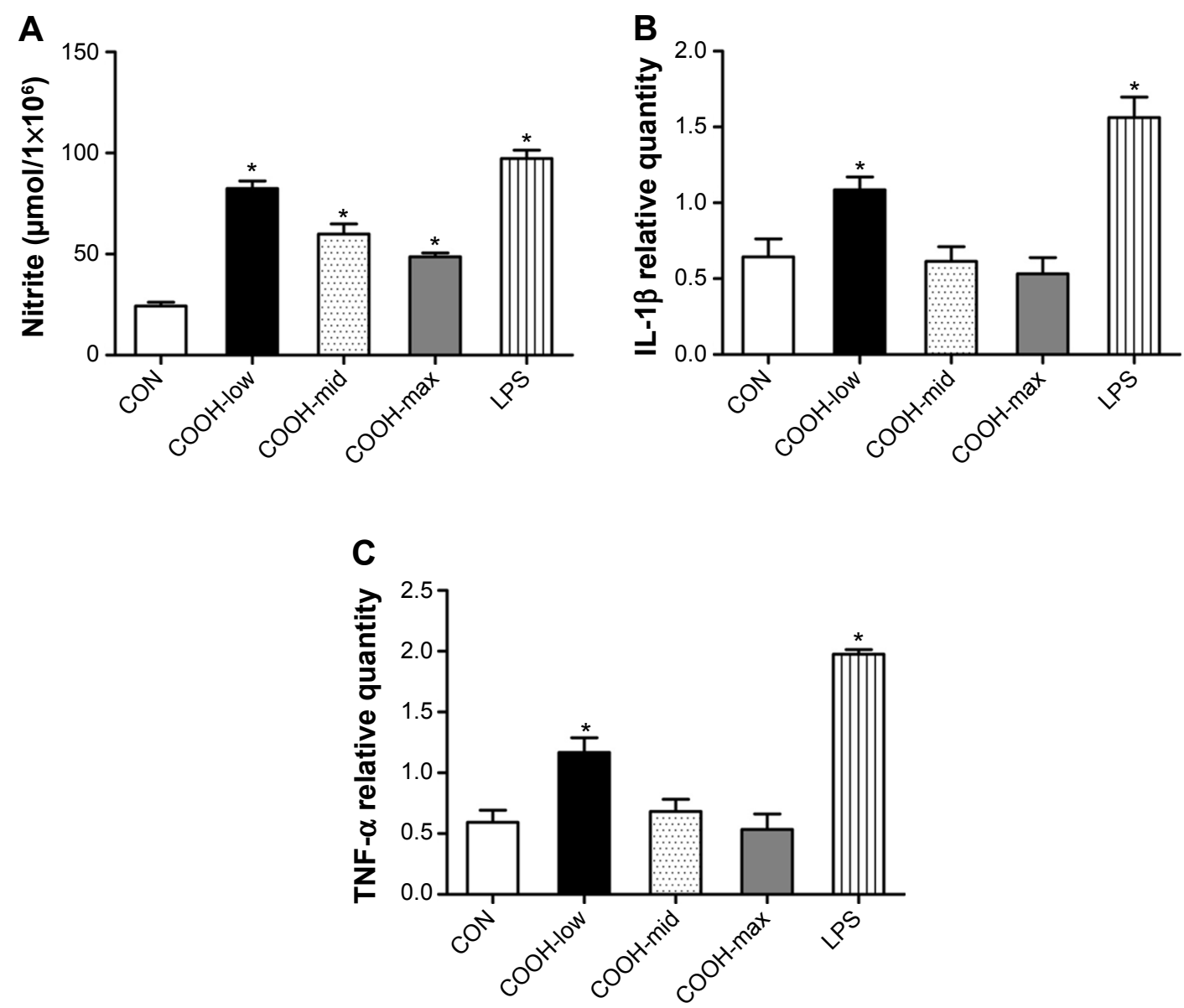

Figure 4 Effects of dispersed single-walled carbon nanotubes on NO production and cytokine expression.

Notes: (A) Cells ( $2 \times 10^{4}$ cells/well in 96-well plates) were treated with I $\mu \mathrm{g} / \mathrm{mL}$ of differently dispersed swCNTs. After treatment for 48 hours, NO production in the culture media was assayed using Griess reagent. Lipopolysaccharide $(30 \mathrm{ng} / \mathrm{mL})$ was used as a positive control. (B, C) Cells ( $2 \times 10^{5}$ cells/well in 24 -well plates) were treated with I $\mu \mathrm{g} / \mathrm{mL}$ swCNTs for 24 hours. Gene expression of (B) IL- I $\beta$ and (C) TNF- $\alpha$ was analyzed using real-time PCR. The results are presented as mean \pm SE of three independent experiments. $* P<0.05$ significantly different from control.

Abbreviations: CON, control; IL, interleukin; LPS, lipopolysaccharide; PCR, polymerase chain reaction; SE, standard error; swCNT, single-walled carbon nanotube; TNF, tumor necrosis factor.

blood cell (WBC) counts in the serum decreased significantly upon exposure to $\mathrm{COOH}-$ low particles, but remained at normal levels for $\mathrm{COOH}-\mathrm{max}$ (Figure 5A). Because WBCs help defend the body against pathogen invasion, a change in the serum WBC count implies an alteration of the immune response. Furthermore, exposure to swCNTs altered the $\mathrm{T}$ lymphocyte population in the spleen (Figure 5B). The spleen, a reticuloendothelial system organ, is a part of the immune system that consists of phagocytic cells located in reticular connective tissue. The spleen is highly sensitive to damage by xenobiotics, and the lymphocyte population of the spleen is important in the immune response. ${ }^{36,37}$ Significant increases in both $\mathrm{CD}^{+}$and $\mathrm{CD} 8^{+} \mathrm{T}$ cells 1 day following intravenously injection of multiwall CNTs (mwCNTs) have been reported, as well as the continued elevation of $\mathrm{CD}^{+}$ T cells through 7 days. ${ }^{38}$ As shown in Figure 5B, although the T lymphocyte population was increased by all dispersed swCNTs, the COOH-max produced a lesser effect on the $\mathrm{T}$ lymphocyte population than that produced by the $\mathrm{COOH}-$ low and $\mathrm{COOH}$-mid. In addition, a splenocyte proliferation assay showed similar effects on the T lymphocyte population (Figure 5C). Other studies indicate good tolerability and no tissue accumulation for water-dispersible highly functionalized mwCNTs in mice. In this regard, a higher degree of functionalization leads to less retention of the nanotubes in tissues. ${ }^{39}$ Therefore, our results suggest that less-dispersed swCNTs increase immunotoxicity, but use of highly dispersed swCNTs (COOH-max) shows lower level of immune function.

Due to change in the T lymphocyte population, we measured the expression of cytokines important for proinflammation (IL-1 $\beta$ and TNF- $\alpha$ ) and proliferation (IL-2) in 
A

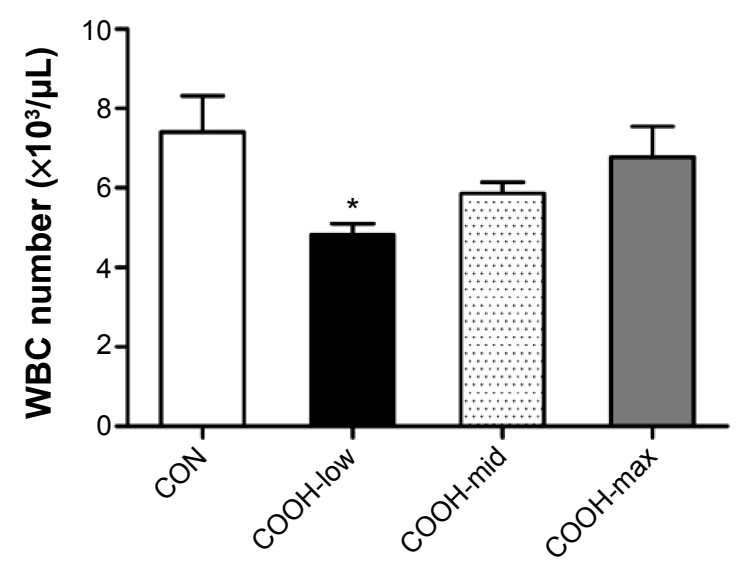

C

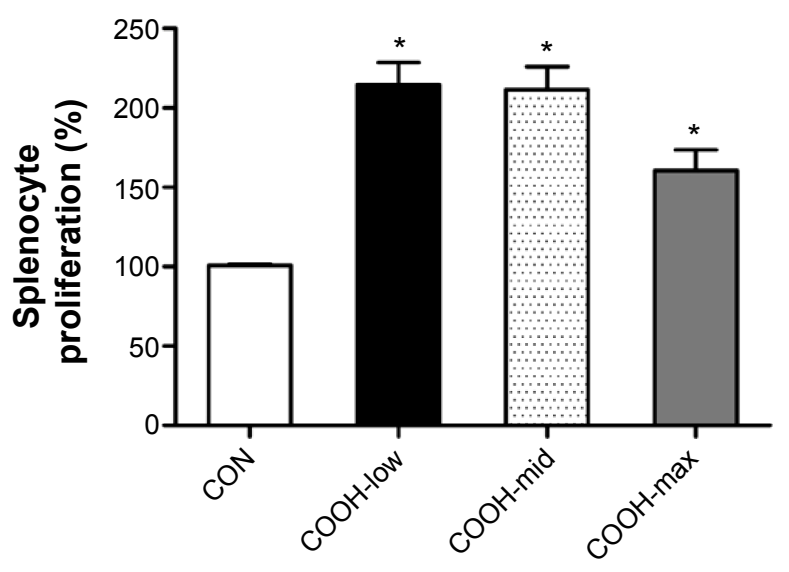

E

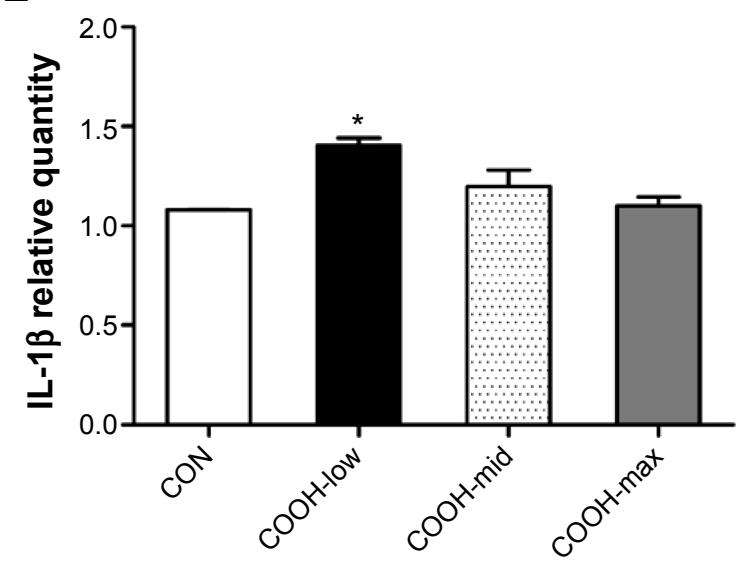

B

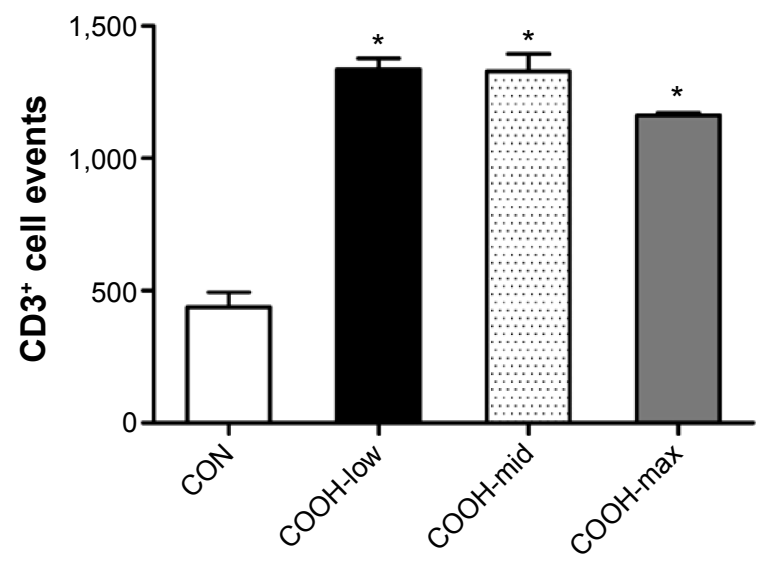

D

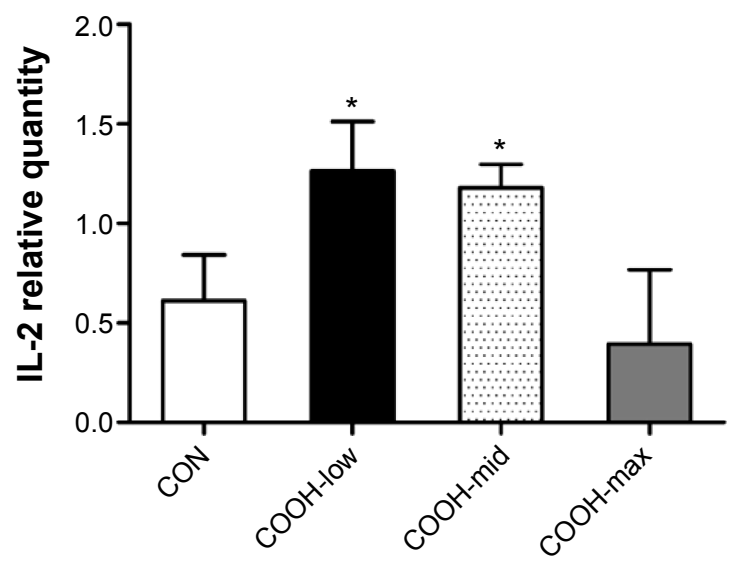

$\mathbf{F}$

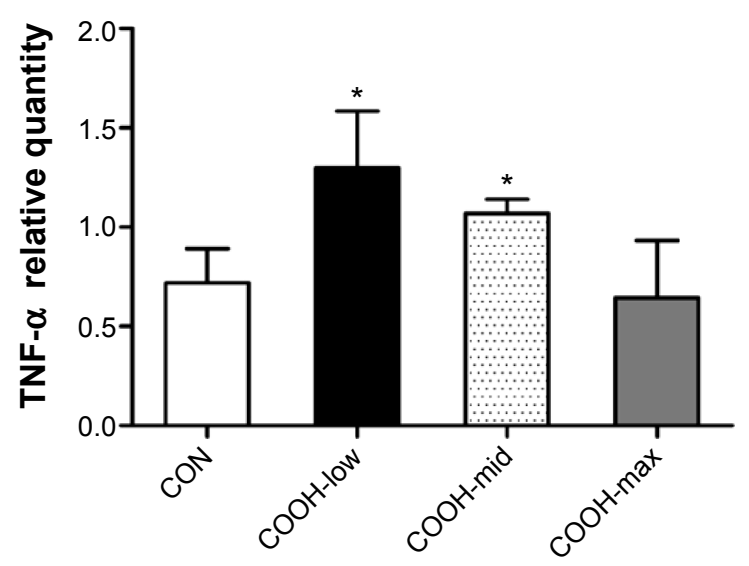

Figure 5 Effects of dispersed single-walled carbon nanotubes on serum WBC count and the spleen.

Notes: Various swCNTs ( $1 \mathrm{mg} / \mathrm{kg} /$ day) were administered to mice by intravenous injection through the tail for 2 weeks. (A) At the end of animal treatment, the mice $(n=10)$ were fasted overnight and euthanized using carbon dioxide. Serum was collected, and WBC count was obtained using a hemocytometer after lysis of RBCs. (B) Flow cytometry analysis of $\mathrm{T}$ lymphocyte $\left(\mathrm{CD}^{+}\right)$populations. T-cell population comprised the absolute number of cells that expressed $\mathrm{CD} 3^{+}$. (C) Splenocytes were isolated and cultured into 96-well plates containing Con A $(10 \mu \mathrm{g} / \mathrm{mL})$ for 72 hours. Cell proliferation is represented by the relative absorbance from Con A-stimulated control splenocytes. Gene expression of (D) IL-2, (E) IL-I $\beta$, and (F) TNF- $\alpha$ in the spleen was analyzed using real-time PCR. The results are presented as mean \pm SE ( $n=10$ ). $* P<0.05$ significantly different from control.

Abbreviations: CON, control; Con A, Concanavalin A; IL, interleukin; PCR, polymerase chain reaction; RBC, red blood cell; SE, standard error; swCNT, single-walled carbon nanotube; TNF, tumor necrosis factor; WBC, white blood cell. 
the spleen (Figure 5D-F). As expected, the highly dispersed COOH-max induced less expression of IL- $1 \beta$, TNF- $\alpha$, and IL-2 than less-dispersed $\mathrm{COOH}-$ low and $\mathrm{COOH}-$ mid. These results indicate that less-dispersed swCNTs may cause immunotoxicity and inflammation in the spleen, while highly dispersed swCNT exhibits normal ranges.

Many studies have been performed on the biological effects of carbon nanotubes, and the interactions between proteins and CNTs (nanoparticle-protein corona) are believed to play an important role in the biological effects of CNTs. ${ }^{40}$ Especially, it was reported that binding of blood proteins to carbon nanotubes reduces cytotoxicity. ${ }^{41}$ In our results, also binding proteins revealed the greatest adsorption amount on $\mathrm{COOH}-$ max (high dispersed swCNT), and $\mathrm{COOH}-\mathrm{max}$ reduced immunotoxicity and inflammation in immune cells and spleen. The formation of the protein corona gives rise to the biological identity of particles, which critically regulates their cell recognition. ${ }^{42}$ Several studies have reported that the protein corona reduces the cell membrane adhesion of particles. ${ }^{43}$ In addition, higher functionalization density on the surface of a CNT results in less reticuloendothelial system accumulation and greater urinary excretion of the CNT. By tuning the degree of surface functionalization of mwCNTs, a greater control over organ biodistribution and clearance could be achieved. ${ }^{44}$ In this regard, mwCNTs with a high degree of oxidation were rapidly cleared from the body through renal excretion without causing nephrotoxicity. The degree of functionalization on carboxylated mwCNTs can influence tissue distribution and toxicokinetic profile. ${ }^{45}$ On the basis of these results, we speculate that highly dispersed swCNTs (COOH-max) induce relatively low immunotoxicity because of rapid excretion from the body.

The swCNTs have generated great interest due to their promising biomedical applications in drug delivery systems. However, application of swCNTs in biomedical fields requires the verification of their potential toxicity. To develop better swCNTs for drug delivery, many researchers have investigated interactions between toxicity and physicochemical properties, such as size distribution, electronic properties, surface properties, solubility, aggregation, and shape. ${ }^{1}$ Functionalization of CNTs, essential for drug delivery, has potential harmful effects upon immune response. We observed that high dispersion of swCNT could mitigate immunotoxicity and inflammation in immune cells and immune organs. Especially, highly dispersed swCNTs diminished immunotoxicity of spleen through reducing the T-cell population and inflammation. In this light, dispersity of swCNTs could be a dominant factor regulating immunotoxicity. Our findings provide a useful guideline for suitable physicochemical states of swCNTs in drug delivery.

\section{Conclusion}

We investigated the immunotoxicity of swCNTs by controlling their physicochemical properties, especially dispersity. Greater carboxyl functionalization made a greater dispersion of swCNTs with small size. Importantly, high carboxylation induced greater adsorption of plasma proteins through increased surface area of swCNTs. These results suggest that high dispersion of swCNT is a source of mitigating immunotoxicity and inflammation in immune cells and immune organs. As a result, dispersity is a critical factor for determining immunotoxicity. Comprehensive understanding of the interaction of various physicochemical properties of swCNTs with protein corona can further elucidate their detailed relationship with toxicity and can thus provide useful safety guidelines for nanotherapeutic drug delivery applications.

\section{Acknowledgments}

This research was supported by grants from the Ministry of Food and Drug Safety of Korea (13182MFDS607), the National Research Foundation of Korea (2014R1A5A2009242, 2013 R 1 A 1 A 3009525 , 2012 M 3 A 9 B 6055416 , 2012R1A1A2041157, and 2014R1A2A1A11052615), and the Korea Health Technology R\&D Project through the KHIDI, funded by the Ministry of Health and Welfare (HI14C1802).

\section{Disclosure}

The authors report no conflicts of interest in this work.

\section{References}

1. Liu Z, Tabakman S, Welsher K, Dai H. Carbon nanotubes in biology and medicine: in vitro and in vivo detection, imaging and drug delivery. Nano Res. 2009;2(2):85-120.

2. Bianco A, Kostarelos K, Partidos CD, Prato M. Biomedical applications of functionalised carbon nanotubes. Chem Commun (Camb). 2005;(5): 571-577

3. Kateb B, Van Handel M, Zhang L, Bronikowski MJ, Manohara H, Badie B. Internalization of MWCNTs by microglia: possible application in immunotherapy of brain tumors. Neuroimage. 2007;37 Suppl 1:S9-S17.

4. Kam NW, O'Connell M, Wisdom JA, Dai H. Carbon nanotubes as multifunctional biological transporters and near-infrared agents for selective cancer cell destruction. Proc Natl Acad Sci U S A. 2005;102(33): 11600-11605.

5. Wu W, Wieckowski S, Pastorin G, et al. Targeted delivery of amphotericin B to cells by using functionalized carbon nanotubes. Angew Chem Int Ed Engl. 2005;44(39):6358-6362.

6. Kam NW, Liu Z, Dai H. Functionalization of carbon nanotubes via cleavable disulfide bonds for efficient intracellular delivery of siRNA and potent gene silencing. J Am Chem Soc. 2005;127(36):12492-12493. 
7. Kam NW, Dai H. Carbon nanotubes as intracellular protein transporters: generality and biological functionality. J Am Chem Soc. 2005; 127(16):6021-6026.

8. Wang J, Xu Y, Yang Z, et al. Toxicity of carbon nanotubes. Curr Drug Metab. 2013;14(8):891-899.

9. Johnson DR, Methner MM, Kennedy AJ, Steevens JA. Potential for occupational exposure to engineered carbon-based nanomaterials in environmental laboratory studies. Environ Health Perspect. 2010;118(1): 49-54.

10. Lee S, Kim MS, Lee D, et al. The comparative immunotoxicity of mesoporous silica nanoparticles and colloidal silica nanoparticles in mice. Int J Nanomedicine. 2013;8:147-158.

11. Yang ST, Wang X, Jia G, et al. Long-term accumulation and low toxicity of single-walled carbon nanotubes in intravenously exposed mice. Toxicol Lett. 2008;181(3):182-189.

12. Mitchell LA, Lauer FT, Burchiel SW, McDonald JD. Mechanisms for how inhaled multiwalled carbon nanotubes suppress systemic immune function in mice. Nat Nanotechnol. 2009;4(7):451-456.

13. Nygaard UC, Hansen JS, Samuelsen M, Alberg T, Marioara CD, Løvik M. Single-walled and multi-walled carbon nanotubes promote allergic immune responses in mice. Toxicol Sci. 2009;109(1):113-123.

14. Bihari P, Holzer M, Praetner M, et al. Single-walled carbon nanotubes activate platelets and accelerate thrombus formation in the microcirculation. Toxicology. 2010;269(2-3):148-154.

15. Chou CC, Hsiao HY, Hong QS, et al. Single-walled carbon nanotubes can induce pulmonary injury in mouse model. Nano Lett. 2008;8(2): 437-445.

16. Li Z, Hulderman T, Salmen R, et al. Cardiovascular effects of pulmonary exposure to single-wall carbon nanotubes. Environ Health Perspect. 2007; 115(3):377-382.

17. Lam CW, James JT, McCluskey R, Arepalli S, Hunter RL. A review of carbon nanotube toxicity and assessment of potential occupational and environmental health risks. Crit Rev Toxicol. 2006;36(3):189-217.

18. Wang J, Sun P, Bao Y, Dou B, Song D, Li Y. Vitamin E renders protection to PC12 cells against oxidative damage and apoptosis induced by single-walled carbon nanotubes. Toxicol In Vitro. 2012;26(1):32-41.

19. Wang L, Castranova V, Mishra A, et al. Dispersion of single-walled carbon nanotubes by a natural lung surfactant for pulmonary in vitro and in vivo toxicity studies. Part Fibre Toxicol. 2010;7:31.

20. Borm PJ, Robbins D, Haubold S, et al. The potential risks of nanomaterials: a review carried out for ECETOC. Part Fibre Toxicol. 2006; $3: 11$.

21. Simeonova PP. Update on carbon nanotube toxicity. Nanomedicine (Lond). 2009;4(4):373-375

22. Wang X, Jia G, Wang H, et al. Diameter effects on cytotoxicity of multi-walled carbon nanotubes. J Nanosci Nanotechnol. 2009;9(5): 3025-3033.

23. Wick P, Manser P, Limbach LK, et al. The degree and kind of agglomeration affect carbon nanotube cytotoxicity. Toxicol Lett. 2007;168(2): $121-131$.

24. Liu Z, Davis C, Cai W, He L, Chen X, Dai H. Circulation and long-term fate of functionalized, biocompatible single-walled carbon nanotubes in mice probed by Raman spectroscopy. Proc Natl Acad Sci U S A. 2008;105(5): 1410-1415.

25. Liu Z, Cai W, He L, et al. In vivo biodistribution and highly efficient tumour targeting of carbon nanotubes in mice. Nat Nanotechnol. 2007;2 (1):47-52.

26. Al Faraj A, Fauvelle F, Luciani N, et al. In vivo biodistribution and biological impact of injected carbon nanotubes using magnetic resonance techniques. Int J Nanomedicine. 2011;6:351-361.
27. Park SJ, Khang D. Conformational changes of fibrinogen in dispersed carbon nanotubes. Int J Nanomedicine. 2012;7:4325-4333.

28. Gao C, He H, Zhou L, Zheng X, Zhang Y. Scalable functional group engineering of carbon nanotubes by improved one-step nitrene chemistry. Chem Mater. 2009;21(2):360-370.

29. Donaldson K, Stone V, Seaton A, MacNee W. Ambient particle inhalation and the cardiovascular system: potential mechanisms. Environ Health Perspect. 2001;109 Suppl 4:523-527.

30. Zhou YM, Zhong CY, Kennedy IM, Leppert VJ, Pinkerton KE. Oxidative stress and NFkappaB activation in the lungs of rats: a synergistic interaction between soot and iron particles. Toxicol Appl Pharmacol. 2003;190(2):157-169.

31. Rzigalinski BA, Meehan K, Davis RM, Xu Y, Miles WC, Cohen CA. Radical nanomedicine. Nanomedicine (Lond). 2006;1(4):399-412.

32. Markovic Z, Trajkovic V. Biomedical potential of the reactive oxygen species generation and quenching by fullerenes (C60). Biomaterials. 2008;29(26):3561-3573.

33. Patil S, Sandberg A, Heckert E, Self W, Seal S. Protein adsorption and cellular uptake of cerium oxide nanoparticles as a function of zeta potential. Biomaterials. 2007;28(31):4600-4607.

34. Yang H, Liu C, Yang D, Zhang H, Xi Z. Comparative study of cytotoxicity, oxidative stress and genotoxicity induced by four typical nanomaterials: the role of particle size, shape and composition. $J \mathrm{Appl}$ Toxicol. 2009;29(1):69-78.

35. Belyanskaya L, Weigel S, Hirsch C, Tobler U, Krug HF, Wick P. Effects of carbon nanotubes on primary neurons and glial cells. Neurotoxicology. 2009;30(4):702-711.

36. Kagan VE, Bayir H, Shvedova AA. Nanomedicine and nanotoxicology: two sides of the same coin. Nanomedicine. 2005;1(4):313-316.

37. Linkov I, Satterstrom FK, Corey LM. Nanotoxicology and nanomedicine: making hard decisions. Nanomedicine. 2008;4(2):167-171.

38. Wang X, Podila R, Shannahan JH, Rao AM, Brown JM. Intravenously delivered graphene nanosheets and multiwalled carbon nanotubes induce site-specific Th2 inflammatory responses via the IL-33/ST2 axis. Int J Nanomedicine. 2013;8:1733-1748.

39. Lacerda L, Ali-Boucetta H, Herrero MA, et al. Tissue histology and physiology following intravenous administration of different types of functionalized multiwalled carbon nanotubes. Nanomedicine (Lond). 2008;3(2):149-161.

40. Lundqvist M, Stigler J, Elia G, Lynch I, Cedervall T, Dawson KA. Nanoparticle size and surface properties determine the protein corona with possible implications for biological impacts. Proc Natl Acad Sci USA. 2008;105(38):14265-14270.

41. Ge C, Du J, Zhao L, et al. Binding of blood proteins to carbon nanotubes reduces cytotoxicity. Proc Natl Acad Sci U S A. 2011;108(41): 16968-16973.

42. Monopoli MP, Aberg C, Salvati A, Dawson KA. Biomolecular coronas provide the biological identity of nanosized materials. Nat Nanotechnol. 2012;7(12):779-786.

43. Lesniak A, Fenaroli F, Monopoli MP, Åberg C, Dawson KA, Salvati A. Effects of the presence or absence of a protein corona on silica nanoparticle uptake and impact on cells. ACS Nano. 2012;6(7):5845-5857.

44. Al-Jamal KT, Nunes A, Methven L, et al. Degree of chemical functionalization of carbon nanotubes determines tissue distribution and excretion profile. Angew Chem Int Ed Engl. 2012;51(26):6389-6393.

45. Jain S, Thakare VS, Das M, et al. Toxicity of multiwalled carbon nanotubes with end defects critically depends on their functionalization density. Chem Res Toxicol. 2011;24(11):2028-2039. 


\section{Supplementary materials}

A

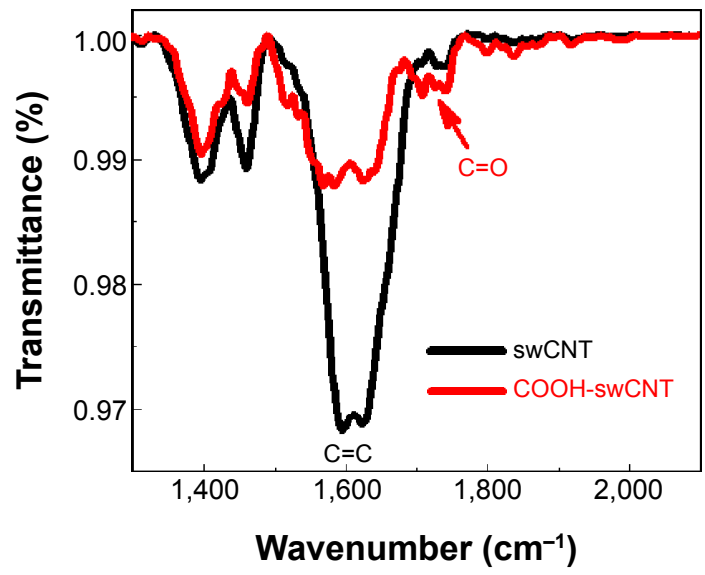

B

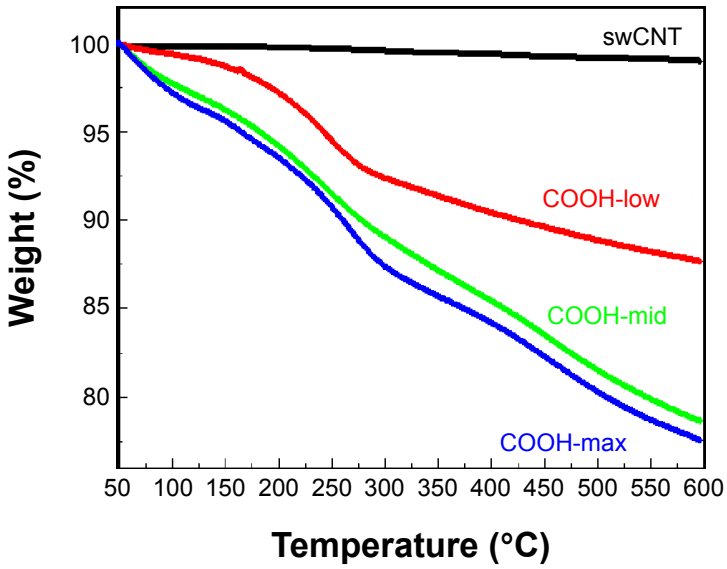

Figure SI Carboxyl functionalization (FTIR) and amount of functionalization on swCNTs (thermal gravimetric analysis).

Notes: (A) FTIR signals for functionalized swCNTs showed increased carboxylate bonds $(C=O)$ at I,720 $\left(\mathrm{cm}^{-1}\right)$, whereas unmodified swCNTs did not exhibit any notable peaks around the $\mathrm{C}=\mathrm{O}$ energy. Signals from crystalline carbon lattice structures $(\mathrm{C}=\mathrm{C})$ diminished after acidic treatment (for functionalization) as identified around I,600 (cm $\left.{ }^{-1}\right)$. (B) The carboxyl weight percentages of $\mathrm{COOH}$-low, $\mathrm{COOH}$-mid, and $\mathrm{COOH}$-max were $12 \%, 21 \%$, and $22 \%\left(\right.$ at $\left.600^{\circ} \mathrm{C}\right)$, respectively.

Abbreviations: FTIR, Fourier transform infrared spectroscopy; swCNT, single-walled carbon nanotube.
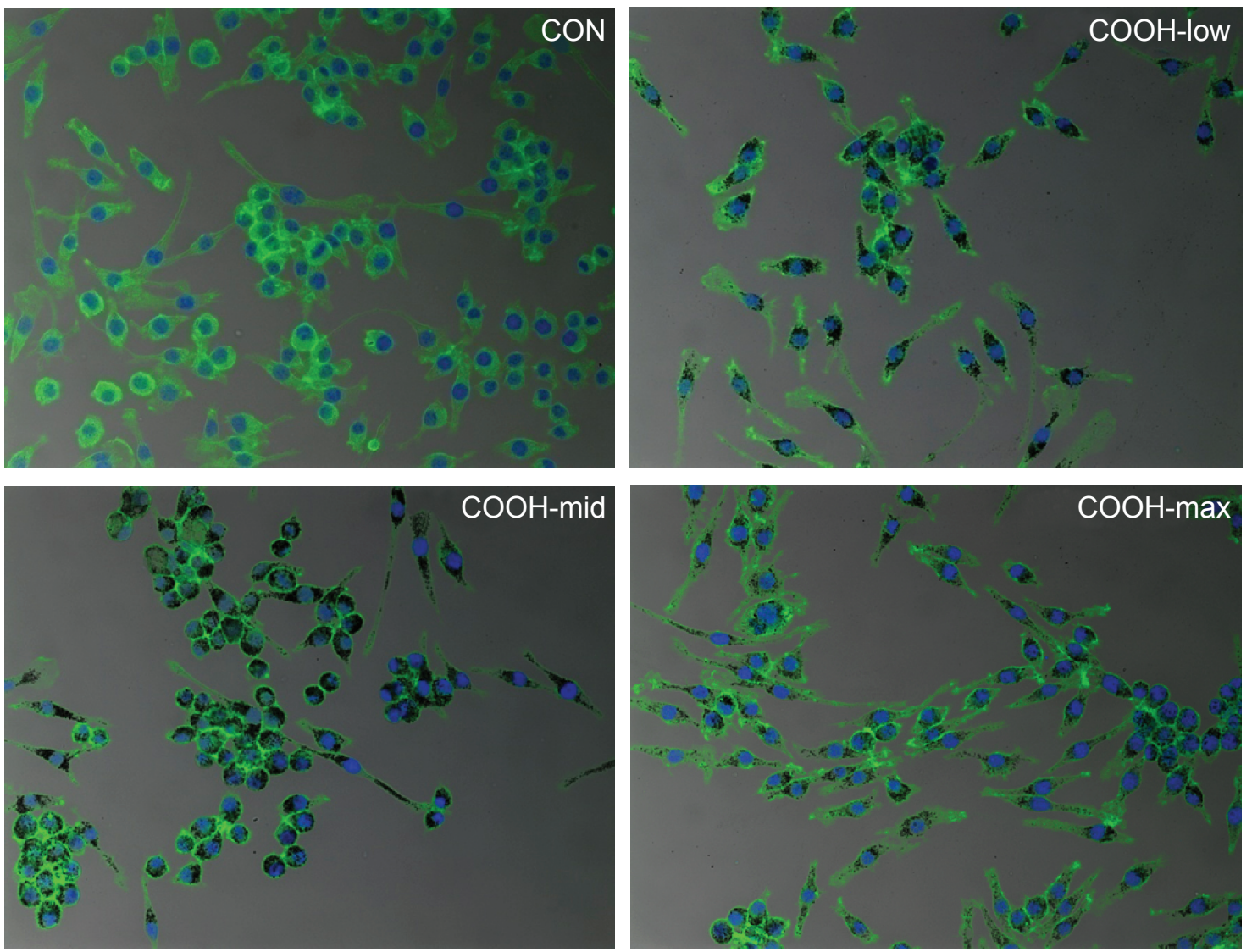

Figure S2 Macrophage uptake of differently dispersed single-walled carbon nanotubes.

Notes: Cells ( $2 \times 10^{5}$ cells/well in 4-well plates) were treated with I $\mu \mathrm{g} / \mathrm{mL}$ swCNTs for 24 hours. After treatment with swCNTs, the cells were stained with F-actin (green) and DAPI (blue). Images showed intracellular location of swCNTs (black). Most of swCNTs were sufficiently uptaken by macrophages, regardless of carboxylation order. The fluorescence was visualized using confocal microscopy $(\times 200)$.

Abbreviations: CON, control; DAPI, 4',6-diamidino-2-phenylindole; swCNT, single-walled carbon nanotube. 

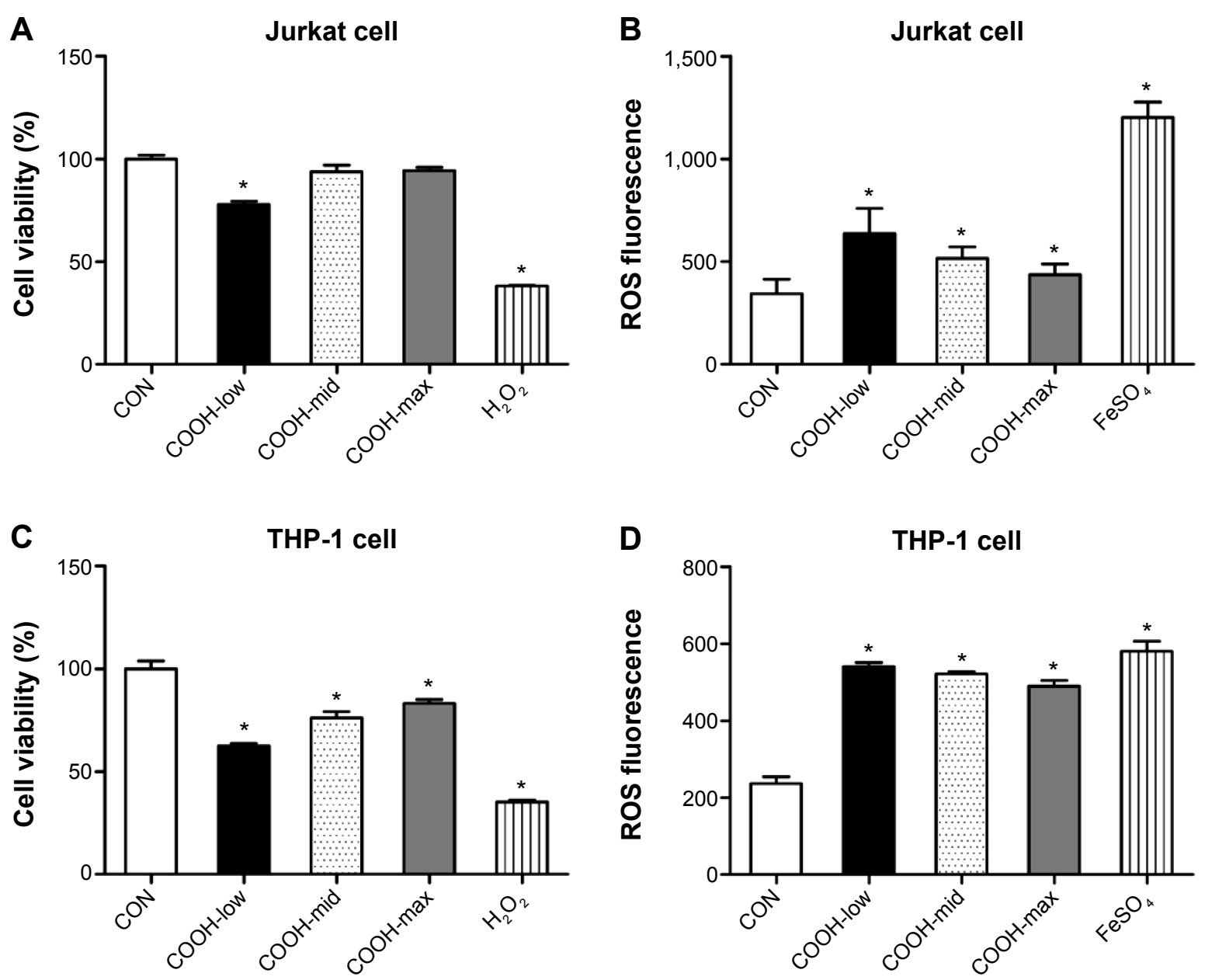

Figure S3 Effects of dispersed single-wall carbon nanotubes on Jurkat and THP-I cytotoxicity.

Notes: (A, B) Jurkat cells. (C, D) THP-I cells. For cell viability, cells $\left(2 \times 10^{4}\right.$ cells/well in $96-$ well plates $)$ were treated with various concentrations of dispersed swCNTs. After 24 hours of treatment, cell viability was determined using the MTT assay. Hydrogen peroxide $(500 \mu \mathrm{M})$ was used as a positive control. For ROS production, cell viability was determined by the relative absorbance compared to control. Cells $\left(2 \times 10^{4} \mathrm{cells} /\right.$ well in $96-$-well plates $)$ were treated with I $\mu \mathrm{g} / \mathrm{mL}$ swCNTs for 24 hours. After treatment, the cells were stained with $10 \mu$ M DHR 123 for 30 minutes. Production of ROS was determined using DHR I23 staining. The fluorescent intensity of DHR was recorded using a fluorescent plate reader. $\mathrm{FeSO}_{4}(100 \mu \mathrm{M})$ was used as a positive control. The results are presented as mean $\pm \mathrm{SE}$ of three independent experiments. $* P<0.05$ significantly different from control.

Abbreviations: CON, control; DHR, dihydrorhodamine; MTT, 3(4,5-dimethylthiazolyl-2)2,5-diphenyl tetrazolium bromide; ROS, reactive oxygen species; SE, standard error; SOD, superoxide dismutase; swCNT, single-walled carbon nanotube.

A

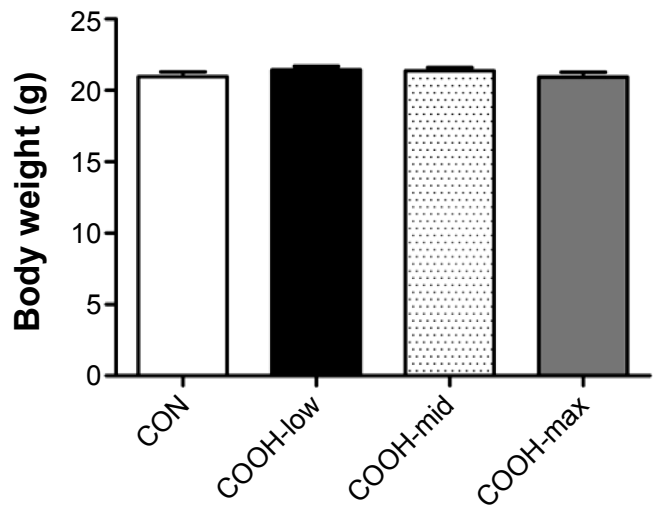

B

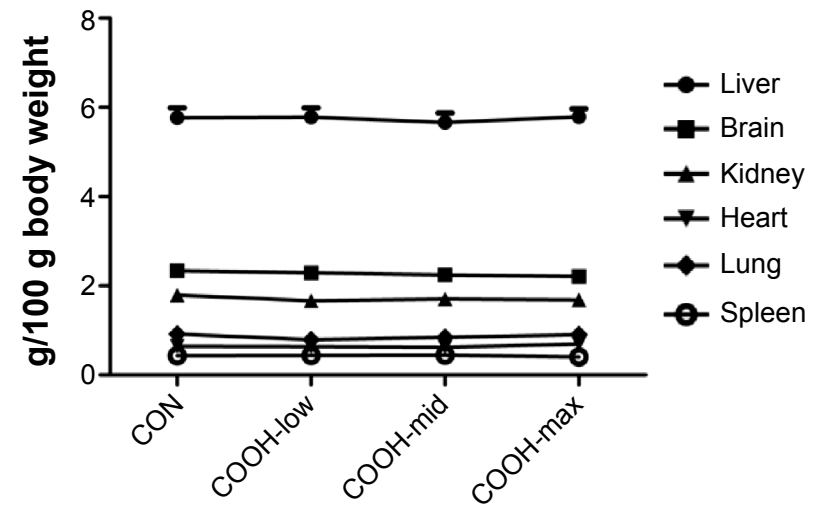

Figure S4 Body and tissue weight changes by dispersed swCNTs.

Notes: (A) Body weight. (B) Tissue weight. Various swCNTs (I mg/kg/day) were administered to mice by intravenous injection through the tail for 2 weeks. At the end of the treatment period, the mice were fasted overnight and euthanized using carbon dioxide. Various organs were aseptically excised and weighed. The results are presented as mean $\pm S E(n=10)$.

Abbreviations: CON, control; SE, standard error; swCNT, single-walled carbon nanotube. 


\section{Publish your work in this journal}

The International Journal of Nanomedicine is an international, peerreviewed journal focusing on the application of nanotechnology in diagnostics, therapeutics, and drug delivery systems throughout the biomedical field. This journal is indexed on PubMed Central,

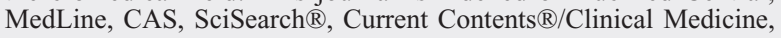

Journal Citation Reports/Science Edition, EMBase, Scopus and the Elsevier Bibliographic databases. The manuscript management system is completely online and includes a very quick and fair peer-review system, which is all easy to use. Visit http://www.dovepress.com/ testimonials.php to read real quotes from published authors.

Submit your manuscript here: http://www.dovepress.com/international-journal-of-nanomedicine-journal 